\title{
The Right to Political Party Membership in Ethiopia: \\ On the Freedom to Join and Resign
}

\section{Abstract}

Leake Mekonen Tesfay *

The FDRE Constitution acknowledges the right to freedom of political party membership. Similarly, the Political Parties Registration Proclamation, which regulates the details of political party membership, allows a political party member to withdraw from his/her membership at any time. The form of withdrawal, however, has become contentious. In Unity for Justice and Democracy Party -versus- Blue Party (a case finally adjudicated by the Cassation Bench of the Federal Supreme Court), the petitioner, claimed that a person cannot be member of another political party without a written withdrawal notice to his/her former political party. The respondent political party, on its part, argued that withdrawal from membership and taking membership in another political party is possible at any time. The points of controversy and the legal framework thereof are examined in this article. An attempt is made to assess relevant principles, international human rights instruments and the experience of other jurisdictions.

\section{Key terms}

Freedom of association · Political party $\cdot$ Membership right $\cdot$ Political pluralism · Freedom of choice $\cdot$ Ethiopia

DOI http://dx.doi.org/10.4314/mlr.v11i2.5

Received: 5 April 2017

Accepted: 30 August 2017

This article is licensed under a Creative Commons Attribution-

NonCommercial-NoDerivs (CC BY-NC-ND)

\section{Introduction}

Multiparty democratic federation is enshrined in Ethiopia’s 1995 Constitution, ${ }^{1}$ in contrast to Ethiopia's former political experience. The reign of Emperor Haile

\footnotetext{
- Leake Mekonen Tesfay (LL.B, Hawassa University; LL.M, Ethiopian Civil Service University), Judge, Federal First Instance Court; E-mail: happyleake@gmail.com

I thank the anonymous internal and external reviewers for their comments. I also thank my dear wife Selamawit Mlaw Kidane for her support throughout the research.
} 
Selassie was notable for not allowing political parties, ${ }^{2}$ while the military regime that followed led to the establishment of a one-party system. The Workers Party of Ethiopia (WPE) was the only political party that was legally recognized. ${ }^{3}$ The Constitution of the Peoples Democratic Republic of Ethiopia (PDRE) of 1987 stated that WPE shall be guided by Marxism-Leninism, and considered it as the vanguard political party dedicated to serve the interests of the working people. ${ }^{4}$ Although the right to association was provided for in the PDRE Constitution, ${ }^{5}$ political associations and political parties other than the WPE were made impracticable.

After the seizure of state power by the Ethiopian Peoples' Revolutionary Democratic Front (EPRDF), the idea of multiparty democracy ${ }^{6}$ was embodied in the 1991 Charter of the Transitional Government of Ethiopia (the Charter) which provided for human and democratic rights and freedoms based on the Universal Declaration of Human Rights. ${ }^{7}$ Particularly, the right to unrestricted political participation and the right to organize political parties were provided for. ${ }^{8}$ Following the Charter, political parties' registration proclamation was proclaimed to provide for the details of multiparty political association. ${ }^{9}$

After the adoption of the FDRE Constitution, multiparty political democracy and political pluralism, though with limitations, ${ }^{10}$ have continued to be among

${ }^{1}$ Constitution of the Federal Democratic Republic of Ethiopia, Proclamation No. 1/1995, (hereinafter called FDRE Constitution).

2 Kassahun Berhanu (2003), "Party Politics and Political Culture in Ethiopia” in M.A. Mohamed Salih (ed.), African Political Parties: Evolution, Institutionalisation and Governance, (London, Sterling and Virgina: Pluto Press), p. 117, (hereinafter called Kassahun).

${ }^{3}$ Ibid.

${ }^{4}$ The Constitution of the Peoples Democratic Republic of Ethiopia Proclamation No. 1 of 1987 (12 ${ }^{\text {th }}$ September 1987) Vol. 47, No. 1, Negarit Gazeta (Addis Ababa), Article 6(1).

${ }^{5}$ Id., Article, 47(1)

${ }^{6}$ Kassahun, supra note 2, p. 119.

${ }^{7}$ Transitional Period of Ethiopia Charter No.1, generally see Article 1.

${ }^{8}$ Id., Article 1 (a)(1).

${ }^{9}$ Political Parties Registration Proclamation, Proc. No. 43 of 1993 (April 27, 1993) 52 ${ }^{\text {nd }}$ Year, No. 37 Negarit Gazeta (Addis Ababa) (now repealed). This proclamation endorses the right to unrestricted political participation and the right to organize political parties as provided for in the Charter (cited supra note 7) and provides for the right to form or join a political party and the right to withdraw from political party membership at any time. See the preamble, Article 4(1), 16 and 20.

10 The multiparty system in Ethiopia is said not to have been formally established in practice, inter alia, because of the hegemonic character of the ruling party, EPRDF, thereby narrowing down the political landscape for opposition parties. See for example, Multiparty System - In Ethiopian Case: 
the fundamental features of the Ethiopian state. The FDRE Constitution acknowledges human and democratic rights, which include the right to association and the right to vote and to be elected. ${ }^{11}$ The right to freedom of political association guarantees individuals the right to freedom of political party membership thereby allowing individuals to establish or join to a political party of their free choice. It is also natural that the freedom to establish or join to a political party carries the other side of the coin -the right to resign (withdraw) from membership.

In the federal arrangement in Ethiopia, the power to legislate on issues relating to elections and political parties is given to the federal government. ${ }^{12}$ Accordingly, the House of Peoples Representatives has proclaimed laws one of which is the Revised Political Parties Registration Proclamation. ${ }^{13}$ This Proclamation regulates the details of political party membership. It provides that every Ethiopian has the right to form or to be a member of a political party ${ }^{14}$ except that judges, members of the Defense Force and members of the Police Force cannot be members of a political party unless they leave their work. ${ }^{15}$ The Proclamation also provides that a political party member may withdraw from his/her membership at any time. ${ }^{16}$ Although this stipulation may seem to lack

\footnotetext{
<https://www.academia.edu/16782612/MULTIPARTY_SYSTEM_IN_ETHIOPIA?auto=download $>$ accessed on 14/06/2017, pp. 17-20. The plurality electoral system currently used in Ethiopia also contributes for the non-accommodative and non-inclusive nature of the political system. See Getachew Assefa W., "Electoral System and Political Pluralism in Ethiopia: A Case for Reform" in Gedion Timotheows and Helen Fikre (eds.), The FDRE Constitution: Some Perspectives on the Institutional Dimension, Ethiopian Constitutional Law Series, Vol. VI., pp. 6-33. The Government seems to admit that the political space has been narrow for the opposition political parties and a reform in electoral system has been taken as an issue of priority to reform. While addressing the joint session of the House of Peoples Representatives and House of Federation (for the new year of 2009 E.C. on 10 October 2017), the president of the FDRE stated that the government is committed to reform the electoral system to replace the plurality system with a more representative system. Whether these official statements would come to fruition is yet to be seen. See for example, Tsegai Berhane (PhD), "Proportional Representation vis-à-vis Democracy: the Case of [would be] Ethiopian Electoral System?”

$<$ http://www.tigraionline.com/articles/ethiopia-electoral-system.html $>$ accessed on 14/06/2017.

${ }^{11}$ FDRE Constitution, supra note 1 , Article 31 and 38.

${ }^{12}$ Id., Article 51(15) and 55(2)(d).

${ }^{13}$ Revised Political Parties Registration Proc. No. 573/2008 (24 $4^{\text {th }}$ September 2008) $14^{\text {th }}$ Year, No. 62 Federal Negarit Gazeta (Addis Ababa), (hereinafter called Political Parties Registration Proclamation).

${ }^{14}$ Id., Article 4(1).

${ }^{15}$ Id., Article 58 (1) and (2).

${ }^{16}$ Id., Article 31(3).
} 
adequate clarity, it does not seem to require any condition or formality; it rather allows a political party member to withdraw at any time.

The form of withdrawal has, however, become a bone of contention. An example for this is a membership and candidacy controversy between Unity for Justice and Democracy Party and Blue Party, a controversy arose relating to the $24^{\text {th }}$ May 2015 Ethiopian election. The case was finally decided by the Cassation Bench of the Federal Supreme Court in Unity for Justice and Democracy Party versus- Blue Party. ${ }^{17}$ The issue of controversy was whether a political party member can withdraw from her/his membership and take membership in another political party without notifying the party of his/her previous membership in writing.

This article examines the existing legal frameworks related with political party membership rights in Ethiopia. It does not address all issues related to the freedom of political party membership, and focuses on freedom of political party membership with due attention to the freedom to join and resign. An attempt is made to examine relevant principles and provisions of international human rights instruments and, the experience of other selected jurisdictions. I argue that the provisions in the relevant laws related to political parties and election, and particularly the Political Parties Registration Proclamation do not require a written withdrawal notice as the sole procedure upon withdrawing from political party membership.

On the one hand, political party members can resign from their previous membership at any time without any condition or formality, and take membership in another political party of their choice. To this end, any political party member who is known to have taken membership in another political party shall be assumed to have terminated his/her previous membership upon her/his will. On the other hand, this article discusses the schemes of avoiding the possible challenges of simultaneous political party membership by which individuals may accept simultaneous nomination as candidates for election by more than one political party.

The first section of the article highlights the issues raised in the Unity for Justice and Democracy Party -versus- Blue Party case, followed by Section 2 which deals with general considerations on the role of political parties and, relevant basic principles and provisions of international human rights instruments. The third section examines the experience of Germany, Israel, Canada and Kenya. The last section discusses the relevant provisions of Ethiopian laws followed by concluding remarks.

${ }^{17}$ Unity for Justice and Democracy Party v. Blue Party, (Federal Supreme Court: Federal Supreme Court Cassation Decisions, Vol. 18, 421-435, Miyaziya 28, 2007 E.C.), (hereinafter called Unity for Justice and Democracy Party v. Blue Party). 


\section{Unity for Justice and Democracy Party v. Blue Party: An Overview}

The litigation in Unity for Justice and Democracy Party -versus- Blue Party commenced in Amhara Region Western Gojjam Zone Daga Damot Wereda (District) Constituency Grievance Hearing Committee. Unity for Justice and Democracy Party (the applicant) petitioned to the Committee that Ato Girma Bitew, Ato Meles Zeleke, W/ro Yirgedu Tadege and Ato Yihune Tilahun, whom the respondent presented as candidates to Daga Damot Constituency for the $5^{\text {th }}$ National election of $24^{\text {th }}$ May 2015, have been members of the applicant till the time they were registered as candidates of the respondent and, requested their dismissal from candidacy. The Committee ruled that the above named candidates are members of the applicant, and it rejected their election candidature under the respondent.

The Blue Party (the respondent) appealed to the Grievance Hearing Committee in the Branch Office of the National Electoral Board of Ethiopia in Amhara Region, which confirmed the decision of the lower committee. The respondent still dissatisfied, appealed to the Supreme Court of Amhara Region. The Court confirmed the decisions of the Committees stating that the respondent did not present evidence to prove that the candidates it presented for the election have withdrawn from their previous membership in accordance with the by-laws of the applicant and have been its members having waited for the time test required for full membership according to its by-laws.

The respondent lodged its petition to the Cassation Bench of Amhara Regional Supreme Court. The Regional Cassation Court (by majority decision) ruled in favour of the respondent. The majority ruling reasoned, inter alia, that the above named candidates -although were the members of applicant- have the right to withdraw from their membership and be members and candidates of the respondent at any time. The court ruled that upon registration as members of the respondent, it should be assumed that they have resigned from their previous membership in the applicant.

The applicant lodged its petition to the Cassation Bench of the Federal Supreme Court. It claimed the candidates presented by the respondent for the election were its members. It contended that the respondent cannot present them as candidates for election without making sure that they have given notice of their resignation to the applicant. The respondent argued that the right to vote and be elected is a constitutionally recognized right, and in effect, every individual who fulfils the requirements can voluntarily be a member of any political party.

Both parties relied on the provisions of the Political Parties Registration Proclamation to support their respective claims. According to the applicant a person cannot be registered as a member and nominated as election candidate of 
another political party without a written withdrawal notice to the political party in which he/she was a member. The respondent on the other side argued that withdrawal from membership is possible at any time and, a political party shall, in its by-law, not limit that right. The respondent added, individuals shall not be forced to remain members of a political party without their will under the pretext that they have not formally withdrawn from it.

The Federal Supreme Court Cassation Bench held that a member of a political party cannot withdraw from his membership and be a member and election candidate of another political party without presenting a written withdrawal notice to the political party in which he/she had membership. The court's detailed reasoning includes its reliance on the experience of developed democracies, particularly mentioning a case from Israel.

\section{General Considerations on Political Party Membership}

\subsection{The role of political parties as political associations in democracy}

Human rights can be either civil or political. Civil rights include freedom of speech, religion and movement; and the right to employment, education, privacy, access to justice, due process, property ownership and nondiscrimination. ${ }^{18}$ Political rights include the civil rights of free speech, voting, etc., and, inter alia, refer to one's ability to participate in government, i.e., to vote and to hold public office, to criticize government, and to advocate change. ${ }^{19}$ Civil rights are universal political rights and oftentimes limited to citizens, ${ }^{20}$ while Human rights have been the interest of all democratic systems. However, human rights provisions cannot be effective unless they are accompanied by enforcement mechanisms. To this end, different constitutions and laws have, in addition to the embodiment of human rights, include provisions for the separation and limitation of state power, due process of law and independent judiciary ${ }^{21}$ for the implementation of human rights.

Political association enables people to come together and reflect their political views that enhance their shared values and enforce their political rights; and political parties are fundamental in these pursuits. ${ }^{22}$ Political parties are

${ }^{18}$ K. Lee Lerner, et al (eds.) (2006), Human and Civil Rights: Essential Primary Sources (Detroit, New York, San Francisco, New Haven, Conn, Waterville, Maine, London and Munich: Thomson Gale), p. 295.

${ }^{19}$ Ibid.

${ }^{20}$ Ibid.

${ }^{21}$ George Kateb (2011), Human Dignity (Cambridge, Massachusetts and London: The Belknap Press of Harvard University Press,), p. 28.

${ }^{22}$ Peter Burnell (2004), Building Better Democracies: Why political parties matter? (Westminster Foundation for Democracy), p. 3. 
manifestations of citizens' right to politically associate. ${ }^{23}$ Direct forms of democracy such as referendums, initiatives and community town-hall meetings can serve limited role in the determination of policies for and the governance of mass societies. ${ }^{24}$ Therefore, political parties are indispensable in modern representative democracy. ${ }^{25}$ In a nutshell, political parties are necessary:

to build and aggregate support among broad coalitions of citizens' organizations and interest groups; to integrate multiple conflicting demands into coherent policy programs; to select and train legislative candidates and political leaders to provide voters with choices among governing teams and policies; and, if elected to office, to organize the process of government and stand collectively accountable for their actions in subsequent contests. ${ }^{26}$

A multiparty system accommodates political parties with different views, and it is more representative than other party systems. ${ }^{27}$ Multiparty system allows multiple political parties to compete with their alternative policies in the interest of people. For a genuine multiparty democratic system, however, the strength of the competing parties is also important. ${ }^{28}$ In the absence of democratic political culture, "[m]ultiparty election exercises conducted on a seemingly competitive basis can serve as smokescreen for perpetuating the power of turncoat 'democrats'."29 Strong competitive parties and fair and ground leveled completion should thus exist ${ }^{30}$ in multiparty elections.

\subsection{Freedom of political party membership: basic principles}

The central foundation for the functioning of political parties is the right to freedom of association ${ }^{31}$ which is also related with the rights of freedom of

${ }^{23}$ OSCE/ODIHR (2011), Guidelines on Political Party Regulation, Adopted by the Venice Commission at its 84 ${ }^{\text {th }}$ Plenary Session Venice, 15-16 October 2010 (Warsaw/Strasbourg: Office for Democratic Institutions and Human Rights (ODIHR)), p. 20.

24 Pippa Norris (2005), Political Parties and Democracy in Theoretical and Practical Perspectives: Developments in Party Communications (National Democratic Institute for International Affairs), p. 3.

25 Ibid.

${ }^{26}$ Id., pp. 3-4.

${ }^{27}$ Anastasija Malachova (Nov. 21, 2012), "Does a Multi-party System Lead to “More” Democracy?” <http://www.e-ir.info/2012/11/21/does-a-multi-party-system-leadto-more-democracy> accessed on 23/01/2017.

${ }^{28}$ Michael Johnston (2005), Political Parties and Democracy in Theoretical and Practical Perspectives: Political Finance Policy, Parties, and Democratic Development (National Democratic Institute for International Affairs), pp. 1-3.

${ }^{29}$ Kassahun, supra note 2, p.129.

${ }^{30}$ Ibid.

31 OSCE/ODIHR and Venice Commission (October 2010), Guidelines on Political Party Regulation, Adopted by the Venice Commission at its $84^{\text {th }}$ Plenary Session (Venice: $15-16$ October 2010), p.8. (hereinafter called Venice Commission Guidelines). 
expression, assembly, ${ }^{32}$ and the right to vote and be elected. The Venice Commission ${ }^{33}$ has adopted principles that need to be considered in designing a political party legislation. Of these principles, five are very significant to understand that political party membership is voluntary in nature and it cannot be limited except for justifiable purposes, hence relevant to discuss them here. ${ }^{34}$

a) The principle of the right of individuals to associate

This principle underlines that "the right of individuals to associate and form political parties should ... be free from interference." 35 Moreover, this principle requires association with political parties to be voluntary in the sense that individuals shall not be "forced to join or belong to any association against their will”. ${ }^{36}$ The principle of protecting the right to politically associate also requires political parties to be free from undue interferences ${ }^{37}$ because it becomes impractical to protect the individual rights of political party members without protecting political parties from undue interferences.

\section{b) The principle of the state's duty to protect individual right of free} association

According to this principle, it is the duty of states to enact laws that are necessary for the practical exercise of the right of citizens to freely associate and

${ }^{32}$ Ibid.

${ }^{33}$ The European Commission for Democracy through Law -commonly known as the Venice Commission as it meets in Venice-is the Council of Europe's advisory body on constitutional matters. The Commission has 61 member states: the 47 Council of Europe member states, and 14 other countries (Algeria, Brazil, Chile, Costa Rica, Israel, Kazakhstan, the Republic of Korea, Kosovo, Kyrgyzstan, Morocco, Mexico, Peru, Tunisia and the USA). Its role is to provide legal advice to its member states; help states wishing to bring their legal and institutional structures in line with European and international standards in the fields of democracy, human rights and the rule of law; work for the dissemination and consolidation of a common constitutional heritage in conflict management; and provide emergency constitutional aid to states in transition. Its individual members are university professors of public and international law, supreme and constitutional court judges, members of national parliaments and civil servants designated for four years by the member states, but they act in their individual capacity. See "The Venice Commission of the Council of Europe"

$<$ http://www.venice.coe.int/WebForms/pages/?p=01_Presentation $>$ accessed on 31/07/2017.

34 The other principles are the principle of non-discrimination, the principle of equal treatment, the principle of good administration of legislation pertaining to political parties, the principle of the right to an effective remedy for violation of rights and the principle of accountability. See Venice Commission Guidelines, supra note 31, pp. 9-11.

${ }^{35}$ Id., p. 9.

${ }^{36}$ Ibid.

${ }^{37}$ Ibid. 
form political parties. ${ }^{38}$ States also have the responsibility to refrain from interference and to make sure that the laws prohibit interference of non-state actors. ${ }^{39}$ Moreover, in cases of violations against the right to association, states are required to provide sufficient remedies to ensure that the violations cease. ${ }^{40}$

c) The principle of legality

According to the principle of legality, any limitation on the right of individuals to freely associate should be expressly articulated in a constitution or parliamentary legislation. ${ }^{41}$ Such limitations should be the result of well studied legitimate justifications necessary for a democratic order but not of partisan political decisions. ${ }^{42}$ This requires the constitution and parliamentary acts of states to respect the right of association found in relevant international human rights instruments, ${ }^{43}$ and political party legislations to be clear thereby indicating what activities are unlawful -including the sanctions in cases of violations. ${ }^{44}$ To help individuals and political parties be aware of their rights and the limitations thereof, political party legislations are required to be adopted only after having passed through open debates and public review. ${ }^{45}$ According to this principle, frequent changes made with respect to party laws may be seen as resulting from political whim rather than satisfying public interest. ${ }^{46}$ While law needs to change with changing social reality, changes in law, including party laws, unwarranted by necessitating reality may be considered arbitrary.

\section{d) The principle of proportionality}

According to the principle of proportionality, limitations imposed on the rights of political parties must be proportional to the specified purposes they are intended to achieve. ${ }^{47}$ The restrictions should be prescribed by law and at the same time necessary for the development of democratic society. ${ }^{48}$ Failing to meet such criteria, they cannot be deemed proportionate. The quote "you must not use a steam hammer to crack a nut, if a nutcracker could do" ${ }^{49}$ depicts the

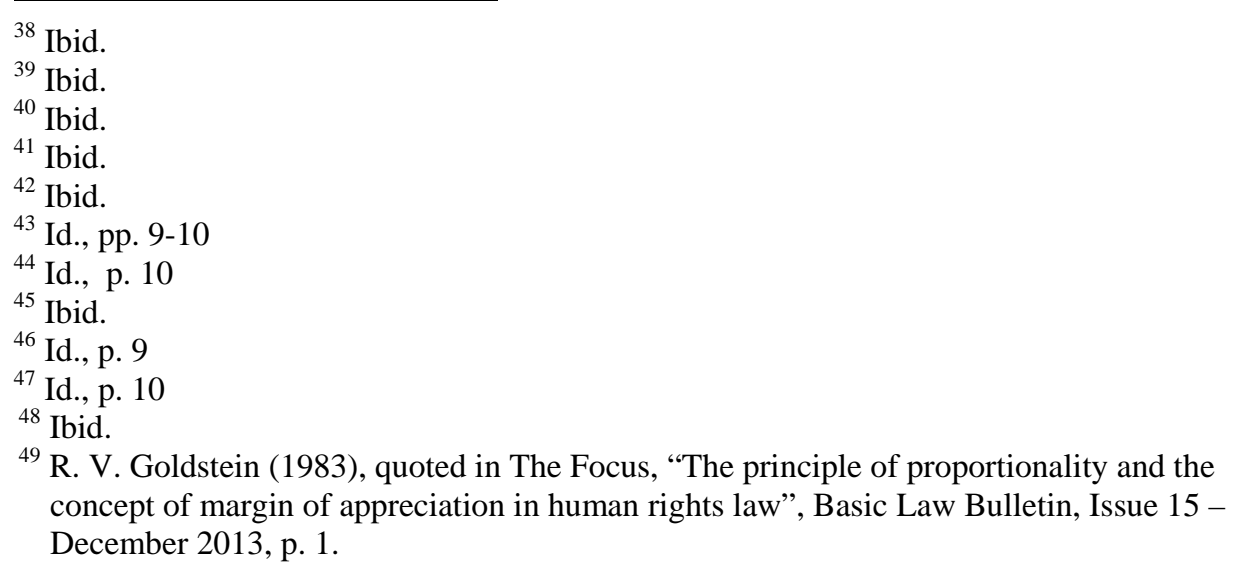


need for proportionality. Limitations should thus be imposed only if they have purposes that cannot be achieved otherwise. ${ }^{50}$

e) The principle of political pluralism

Political pluralism refers to the existence and enhancement of diverse political views. According to this principle, the aim of political party legislations should be facilitating a pluralistic political environment ${ }^{51}$ and citizens should be able to receive a variety of alternative political viewpoints. ${ }^{52}$ In order for individuals to be able to exercise their freedom of choice, they shall be offered real choice. ${ }^{53}$ In other words, citizens shall not be given only deliberately restricted choices -in such a manner that indirectly limits their freedom of choice. Therefore, laws pertinent to regulating political parties should be carefully designed to create a political environment conducive to political pluralism ${ }^{54}$ whereby various political associations having different views will be available so that citizens can freely choose among competing policy platforms.

\subsection{International human rights instruments pertaining to freedom of political party membership}

The Universal Declaration of Human Rights provides "Everyone has the right to freedom of ... association" 55 and "No one may be compelled to belong to an association". ${ }^{6}$ The International Covenant on Civil and Political Rights also provides for the right to freedom of association. ${ }^{57}$ The same holds for the regional human rights instruments, such as the ones that are adopted in Europe and Africa.

Council of Europe, Convention for the Protection of Human Rights and Fundamental Freedoms (the Convention) acknowledges the right to peaceful

\footnotetext{
${ }^{50}$ For more on proportionality, see, for, example Tsegaye Rregassa, "Making Legal Sense of Human Rights: The Judicial Role in Protecting Human Rights in Ethiopia,", Mizan Law Review, Vol. 3, No.2, September 2009, pp. 313-316; Jill Marshall (2009), "Personal Freedom through Human Rights Law? Autonomy, Identity and Integrity under the European Convention on Human Rights", International Studies in Human Rights, Volume 98, (Leiden and Boston: Martinus Nijhaff Publishers) pp. 38-42; and Dieter Grimm, "Proportionality in Canadian and German Constitutional Jurisprudence” (2007), 57 University of Toronto Law Journal.

${ }^{51}$ Venice Commission Guidelines, supra note 31, p. 10.

${ }^{52}$ Ibid.

${ }^{53}$ Ibid.

${ }^{54}$ Ibid.

${ }^{55}$ Universal Declaration of Human Rights (1948), Article 20(1).

${ }^{56}$ Id., Article 20(2).

${ }^{57}$ International Covenant on Civil and Political Rights (1966), Article 22(1).
} 
assembly and freedom of association, ${ }^{58}$ and forbids restrictions except in cases necessary to protect national security, public safety or the rights of others. ${ }^{59}$ Subject to the special nature of their work, however, the Convention allows member states of the European Union to restrict the exercise of these rights by members of the armed forces, members of the police or members of the state administration. ${ }^{60}$ The right to peaceful assembly and association are also provided in the Charter of Fundamental Rights of the European Union (the Charter). ${ }^{61}$ Particularly, the Charter recognizes the contribution of political parties in the expression of the political will of citizens ${ }^{62}$ and hence it acknowledges the right to form or join to political parties.

Likewise, the African Charter on Human and Peoples' Rights (ACHPRs) provides "a normative framework for the African regional human rights system". ${ }^{63}$ It, inter alia, states that everyone has the right to lawful association ${ }^{64}$ and assembly. ${ }^{65}$ In addition to the (ACHPRs), the African Charter on Democracy, Elections and Governance (ACDEG) has been adopted to enhance electoral democracy in Africa ${ }^{66}$ by promoting adherence to universal principles of democracy; regular, free and fair elections for democratic change of governments; and establishment of conditions necessary for transparent and participatory system of government with free access to information including freedom of press. ${ }^{67}$

It is particularly provided that African states signatory to the ACDEG are required to strengthen political pluralism by recognizing the role, rights and responsibilities of political parties, ${ }^{68}$ and by giving opposition political parties legal status under their national laws. ${ }^{69}$ With the view to enhance multiparty

${ }^{58}$ Council of Europe, Convention for the Protection of Human Rights and Fundamental Freedoms (4.XI.1950) (as amended by Protocols No. 11 and No. 14Rome)) Article 11(1).

${ }^{59}$ Id., Article 11(2).

${ }^{60}$ Ibid

${ }^{61}$ The Charter of Fundamental Rights of the European Union (2000/c 364/01), Article 12(1)

${ }^{62}$ Id., Article 12(2).

63 Tikikel Alemu (2007), "The African Charter on Democracy, Elections and Governance: A Normative Framework for Analysing Electoral Democracy in Africa”, LL.M Thesis (Faculty of Law, University of the Western Cape) 'unpublished,' p. 16.

${ }^{64}$ African Charter on Human and Peoples Rights (1981), Article 10.

${ }^{65}$ Id., Article 11.

${ }^{66}$ Richard Lee (19 $9^{\text {th }}$ January 2012), "New era for democracy in Africa," $<$ http://www.osisa.org/hrdb/regional/new-era-democracy-africa> accessed on 03/10/2017; Stacy-Ann Elvy (2013), “Towards a New Democratic Africa: The African Charter on Democracy, Elections and Governance” Emory International Law Review [Vol. 27] p. 47.

${ }^{67}$ African Charter on Democracy, Elections and Governance (adopted on 30 January 2007), Article 2(1), (3) and (10).

${ }^{68}$ Id., Article 3(11)

${ }^{69}$ Ibid. 
elections, states are required to ensure that parties and candidates contesting in election have fair and equitable access to state controlled media. ${ }^{70}$ The African Commission on Human and Peoples' Rights has also passed a resolution that recognizes the right for the existence of various political parties and the right to a pluralist democracy. ${ }^{71}$

The international human rights instruments highlighted in this section show that political party membership is a basic right which is required to be exercised freely and cannot be limited except in cases justified to protect public interest and the right of others, if these cannot be served without compromising this basic right. For these international human rights instruments to take effect, national human rights institutions are required to incorporate the principles and relevant clauses of the charters and conventions into national laws and implement them.

This envisages "the dissemination of information" and the active involvement of state and non-state actors such as NGOs and civil societies, parliamentarians, judiciary, the legal profession at large and political parties. ${ }^{72}$ Particularly, states are required to enact political party laws which define political parties, and stipulate the substantive and procedural requirements to be recognized as political party, the activities that political parties can engage in, norms to be followed by political parties, the sanctions against political parties that do not follow the laws, and details of political financing. ${ }^{73}$

The extent to which the principles and provisions of international human rights instruments are incorporated in domestic laws and the level of their application may vary within jurisdictions. The next section discusses the comparative experience in selected countries regarding the issue of whether political party members who intend to withdraw from their membership and take membership in another political party are required to submit a written withdrawal notice to their former political party.

${ }^{70}$ Id., Article 17(3).

${ }^{71}$ African Commission on Human and Peoples' Rights (2011), ACHPR/RES.184 (EXT.OS/IX) 2011: Resolution on Electoral Processes and Participatory Governance in Africa, p. 2.

72 See Permanent Forum on Arab-African Dialogue on Democracy and Human Rights (2010), The African Charter on Democracy, Elections and Governance: The Role of National Human Rights Institutions (NHRIs) (Cairo: UNESCO) p. 12; and Patrick J. Glen (2012), "Institutionalizing Democracy in Africa: A Comment on the African Charter on Democracy, Elections and Governance” African Journal of Legal Studies 5, p. 172.

73 Jean-Benoit Pilet, et al (2012, Criteria, Conditions and Procedures for Establishing a Political Party in the Member States of the European Union (European Parliament, Directorate General for Internal Policies), pp. 56-57. 


\section{Comparative Experience: Germany, Israel, Canada and Kenya}

\subsection{The German experience}

Germany is referred to as the "heartland of party law". ${ }^{74}$ Its Political Parties Act of 1967 embodies comprehensive and detailed provisions that serve as a model for many national party laws. ${ }^{75}$ Biezen and Borz classify the process of party constitutionalization in Europe into five waves, and they categorize the German case under the first wave. ${ }^{76}$ The German Basic Law acknowledges the role of political parties in the expression of public will and the free association of political parties. It provides that "[p]olitical parties shall participate in the formation of the political will of the people. They may be freely established."77

Details pertaining to political parties in Germany are regulated by federal laws. ${ }^{78}$ Scholars classify the European journey of political party regulation with party laws into three phases and, the first phase includes Germany. ${ }^{79}$ The German party law acknowledges political parties as integral to the free democratic basic order. ${ }^{80}$ It states that "political parties shall participate in forming the people's political will in all fields of public life ...”. ${ }^{81}$ It defines political parties as:

... associations of citizens which, on a continuing basis or for a longer period of time, wish to influence the development of informed political opinion at the federal level or in any of the Länder and to participate in representing the people in the German Bundestag or a Land parliament (Landtag). ${ }^{82}$

${ }^{74}$ Ingrid van Biezen and Gabriela Borz (2009), "The Place of Political Parties in National Constitutions: A European Overview” The Legal Regulation of Political Parties working paper 01/09, p.2 (hereinafter called The Place of Political Parties).

${ }^{75}$ Fernando Casal-Bértoa, et al (March 2012), "Party Law in Comparative Perspective” The Legal Regulation of Political Parties Working Paper 16/12, p. 5 (hereinafter called Fernando Casal-Bértoa, et al).

${ }^{76}$ The first wave covers the years from party constitutionalization in Iceland in 1944 to that of Germany in 1949. For the five waves of party contitutionalization, see The Place of Political Parties, supra note 74, pp. 11-15.

${ }^{77}$ Basic Law for the Federal Republic of Germany, (As at Nov. 2012), Article 21(1).

${ }^{78}$ Id., Article 21(3).

${ }^{79}$ While the study of constitutionalization of political parties in Europe is classified in five waves of development, the regulation of political parties with party laws is studied in three phases. According to the study of political party regulation with party laws in Europe, the first phase includes the enactment of party law of Germany in 1967, that of Finland in 1969 and that of Australia in 1975. For the three phases of party law development, see Fernando Casal-Bértoa, et al, supra note 75, pp. 3-6.

${ }^{80}$ Political Parties Act of 24 July 1967, last amended by the Ninth Act amending the Political Parties Act, of 22 December 2004 (Federal Law Gazette I 2004), Article 1(1).

${ }^{81}$ Id., Section 1(2).

${ }^{82}$ Id., Section 2(1). 
The German party law has provisions that deal with membership and its termination. It provides "only natural persons may be members of a political party," 83 and "persons who, by judicial decision, have been deprived of their right to stand for election or their right to vote, may not be members of a political party." Party statutes are required to contain provisions including, inter alia, procedure of joining and leaving the party ${ }^{84}$ and rights and duties of members. ${ }^{85}$

According to the German party law, political party members may terminate their membership at any time and without a written notice to the political party of their membership. It is provided that "a member shall be entitled at any time to end his/her party membership with immediate effect" ${ }^{86}$ This provision seems to deal with the time element without expressly addressing the issue of form, and hence there can be an argument that this does not necessarily imply that a written notice may not be requested from a withdrawing political party member.

However, this author argues that a political party member may express her/his intention to withdraw not solely by a written notice. Other means of withdrawal such as taking a new membership in another political party or even orally declaring that $\mathrm{s} / \mathrm{he}$ is no more a member should suffice without the need for written notice. So, the express provision as to time seems to have (within it) an implicit meaning as to form entitling a political party member to resign from membership even without a written resignation notice. The fact that a written withdrawal notice is not expressly provided as a requirement in the law also supports this view.

\subsection{The Israeli experience}

Simultaneous political party membership is a criminal offense in the Israeli law. ${ }^{87}$ The criminalization of simultaneous membership in more than one political party does not seem to mean, however, political party members cannot leave their membership and join another party without a written notice to the party they previously were members.

An issue of debate in the Israeli system is party-splitting in the parliament (Knesset) after election. Those who support strong party-discipline and oppose party-splitting -after a seat is secured in the Knesset- argue that "Knesset members who leave the faction in which they were elected or decide to form a splinter group are betraying the voters' trust," and "the mere existence of an

${ }^{83}$ Ibid.

${ }^{84}$ Id., Section 6(2).

${ }^{85}$ Id., Section 6(2) and (3).

${ }^{86}$ Id., Section $10(2)$.

${ }^{87}$ Zvi Ofer and Brenda Malkiel (October 2011), Reforming Israel's Political System: Recommendations and Action Plan (The Forum for Political Reform), p. 18. 
option to break away accords individual MKs numerous opportunities to threaten party cohesion, coalition longevity and government stability". ${ }^{88}$ Those who oppose strong party-discipline and support splitting, on their part, argue "MKs are supposed to serve the public not only through their respective parties but out of loyalty to what they perceive as the public interest," and "MKs must act according to their conscience, even if loyalty to their principles leads them to leave their factions." ${ }^{89}$

To strike a balance, effort has been made to make splitting in the Knesset difficult by imposing certain threshold conditions since $1991{ }^{90}$ Among these conditions was the requirement of at least one-third of the faction's members departing. ${ }^{91}$ And this stringent condition has been amended to provide that "if at least seven MKs resign from a faction, even if they do not constitute one third thereof, no major sanctions will be imposed." 92 The amendment was opposed and its repeal has been recommended. ${ }^{93}$

The Constitution of Israel does not prohibit a political party member who is not in the parliament (Knesset) from terminating his/her political party membership without written notice. The relevant provision reads:

A Knesset member seceding from his faction and failing to tender his resignation as a Knesset member in close proximity to his secession, shall not be included, in the election for the next Knesset, in the list of candidates submitted by a party that was represented by a faction of the outgoing Knesset; This provision does not apply to the splitting of a faction under the conditions prescribed by law. ${ }^{94}$

This provision requires an MK seceding from his/her political party (in order to be included in the list of candidates in the next election by a political party having a sit in the outgoing Knesset) to tender his/her resignation to the Knesset, not to the political party from which s/he is seceding. This provision may seem as if an MK seceding from his faction is required to tender his/her secession to the political party of her/his membership. However, this interpretation cannot be valid if the provision is understood in light of its title and expression. The title of this provision is about the restriction on the candidacy of Knesset members. ${ }^{95}$

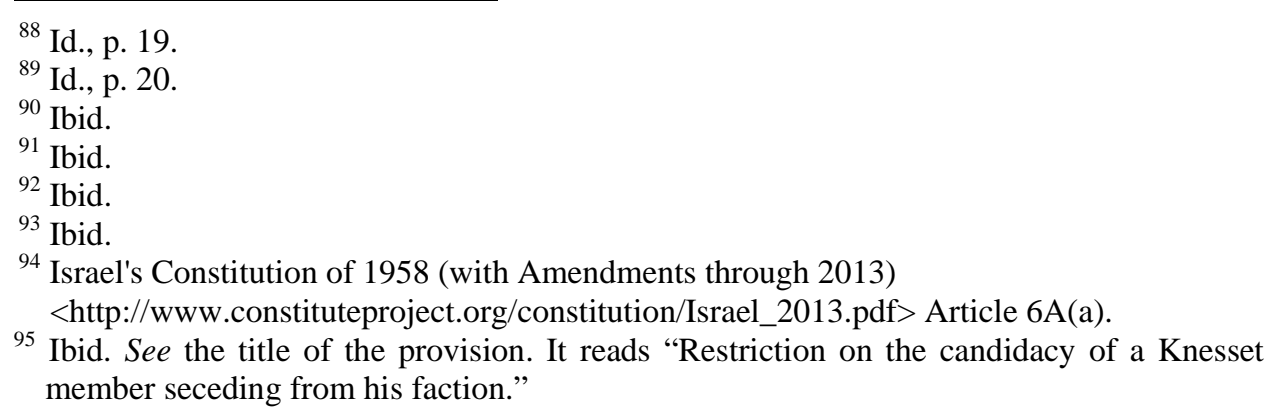


Similarly, the expression in the provision "... failing to tender his resignation as a Knesset member ..." shows that the resignation notice is required to the Knesset.

The latter interpretation is in line with the legislative purpose of the provision that can be understood from its legislative history. Such restriction on MKs constitutes an anti-defection law in order to prevent non-ideological defection in the Knesset by which MKs who defect (from their membership in one political party to another political party) due to a promise for a safe seat in the next Knesset will be forced to resign. ${ }^{96}$ This does not, however, indicate the intention to require a withdrawing political party member to present a written notice to the political party from which s/he is withdrawing.

An MK who resigns from political party membership without documenting resignation to the Knesset, cannot be nominated as candidate in the coming election by a political party having a seat in the outgoing Knesset, unless at least seven Knesset members split from the political party having a seat in the Knesset. This is meant to prevent solicited party-splitting in the Knesset and avoid government failure.

Owing to problems that result from Israel's electoral system, ${ }^{97}$ small and medium sized political parties have got prominence in making and breaking coalitions leading to instability in government. ${ }^{98}$ The anti-defection law is thus meant to address this challenge. However, these anti-defection remedies do not seem to require political party members (who intend to withdraw from their membership) to present a written notice to the political party of their membership. Moreover, political party members cannot be prohibited from withdrawing and taking membership in another political party merely because they have not -in writing- notified their withdrawal from the former political party.

\subsection{The Canadian experience}

The Canadian Charter of Human Rights and Freedoms acknowledges the right to freedom of association. ${ }^{99}$ Since the 1990s, Canadian national politics has

${ }^{96}$ See Csaba Nikoleyni and Shaul Shenhave, "In Search of Party Cohesion: The Emergence of Anti-Defection Legislation in Israel and India” paper prepared for delivery at the Annual Meeting of the American Political Science Association, Toronto, Canada, 3-6 September 2009 (hereinafter called In Search of Party Cohesion).

${ }^{97}$ See for example, Alex Bain (February 2011), “Israel's Flawed Electoral System: Obstacle to Peace and Democracy” Middle East Institute Policy Brief No. 32, p.4-5.

98 Ibid.

99 The Canadian Charter of human Rights and Freedoms, $<$ http://publications.gc.ca/site/archive- 
taken a full-fledged multi-party system, ${ }^{100}$ and as of 2007 there were fifteen registered political parties. ${ }^{101}$ In order for a political party to be recognized and participate in an election, it needs to be registered with the Chief Electoral Office after having applied for registration at least sixty days before the issuance of the notice of election. ${ }^{102} \mathrm{~A}$ party applying for registration is required to present documents including "the names and addresses of at least [two hundred fifty] electors and their signed declarations that they are members of the party and that they support its application for registration". ${ }^{103}$ The Canada Elections Act, does not, however, regulate the details of political party membership. Political parties determine these issues in their constitutions.

According to the Constitution of the Liberal Party of Canada, an applicant who, inter alia, while s/he is a member of the Liberal Party, has not publicly declared his/her intention to partake in an election as a candidate of a party other than the Liberal Party can be a member. ${ }^{104}$ Similarly, the Conservative Party of Canada provides that every citizen or permanent resident of Canada, who, among other requirements, "is not an individual holding a membership in another federal political party" can be a member. ${ }^{105}$ This requirement is also provided in the Constitution of the New Democratic Party of Canada. ${ }^{106}$

From these political party statutes, it is possible to understand that simultaneous political party membership is impossible and a person cannot be simultaneously nominated for an election by more than one political party. However, none of these Canadian political parties regulates the details of

archived.html/?url=http://publications.gc.ca/collections/collection/CH37-4-3-2002E.pdf> Section 2(d).

100 Jay Makarenko (Jun 1, 2010), "Political Parties and the Party System in Canada: History, Operation and Issues," <http://mapleteafweb.com/features/political-parties-and-partysystem-canada-history-operatio-and-issues> accessed on 11/06/2016.

101 Chief Electoral Officer of Canada (2007), The Electoral System of Canada (Public Enquiries Unit, Elections Canada, $2^{\text {nd }}$ Ed.) p. 9.

${ }^{102}$ Chief Electoral Officer of Canada (2007), The Electoral System of Canada (Public Enquiries Unit, Elections Canada, $4^{\text {th }}$ Ed.) p. 30.

103 Id., p. 31.

104 The Liberal Party of Canada, Constitution: As adopted and amended at the Biennial Convention on November 30 and December 1, 2006, further amended at the Biennial Convention in Vancouver on May 2, 2009, and at the Extraordinary Convention on June 18, 2011, and ratified by the National Board of Directors on July 9, 2011 $<$ www.liberal.ca/2010/05/lpc-2009-constitution-en.pdf > Section 4 \& 9.

${ }^{105}$ Conservative Party of Canada, Constitution: As amended by the delegates to the National Convention on November 2, 2013, as consolidated by the National Constitution

Committee and approved by National Council $<$ www.conservative.ca/media/documents/constitution-en.pdf $>$ Section 4.

${ }^{106}$ Constitution of the New Democratic Party of Canada, Effective April 2013 <www.xfer.ndp.ca/2013/constitution/2013-CONSTITUTION-E.pdf> Article 3. 
resignation, and they do not put a requirement that a member intending to resign should present a written withdrawal notice.

This trend is also followed by the Constitution of the South Africa's African National Congress (ANC). The Constitution of the ANC does not provide for details of resignation, rather it provides, "Any member who joins a political organisation or party other than the ANC or a party in alliance with the ANC shall be automatically expelled ...”. ${ }^{107}$ Therefore, membership in another political party suffices for automatic expulsion from the previous political party, and this shows that members cannot be prohibited from the de facto termination of their previous membership by taking new membership in another political party without being obliged to submit a prior written notice to the political party of their previous membership.

\subsection{The Kenyan experience}

Kenya has reintroduced multiparty politics since 1991, and as of March 2005 there were fifty registered political parties. ${ }^{108}$ The Constitution of Kenya provides for the right to freedom of association, and a multiparty political system. ${ }^{109}$ The Kenyan Political Parties Act provides that political parties can be formed subject to law, and every Kenyan citizen can, subject to law contest for an election in a political party of her/his membership. ${ }^{110}$ Political parties need registration to run as political parties. ${ }^{111}$ As criteria for registration, a political party needs to have a constitution which shows, inter alia, the name of the political party including any abbreviation, logo, symbol and party colours; the objectives of the political party and the requirements of admission to and resignation from membership. ${ }^{112}$

The Kenyan Political Parties Act which prohibits simultaneous membership in more than one political party ${ }^{113}$ provides details about resignation from membership. It provides that a political party member who intends to resign

107 “African National Congress Constitution (ANC)” in National Democratic Institute (2011), A Compilation of Political Party Statutes, (Washington, DC), Section 4.19(b).

${ }^{108}$ Centre for Governance and Development (March 2005), "Political parties to be funded by the state” CGD Policy Brief, p. 1.

${ }^{109}$ National Council for Law Reporting, Republic of Kenya (2010), “The Constitution of Kenya” in National Council for Law Reporting, Republic of Kenya (2010), Laws of Kenya (Rev. Ed.), Section 36, $81_{\mathrm{ff}}, 91$ and 92.

${ }^{110}$ National Council for Law Reporting, Republic of Kenya (2012), "Political Parties Act, 2012,” in National Council for Law Reporting, Republic of Kenya (2012), Laws of Kenya (Rev. Ed.), Section 3(1) and (2) (hereinafter called Kenyan Political Parties Act)

${ }^{111}$ Id., Section 4(1).

${ }^{112}$ Id., see the Second Schedule attached to the Act.

${ }^{113}$ Id., Section 14(4) it reads "A person shall not be a member of more than one political party at the same time.” 
shall give a prior written notice to the political party or to the clerk of the House of Parliament, if the member is a Parliament member or to the clerk of the county assembly, if the member is a county assembly member. ${ }^{114}$ On the other hand, the Kenyan Political Parties' Act has provided for other facts by which voluntary resignation from political party membership can be established by a presumption than a written notice. It provides that a political party member who forms or joins to another party, or in any way publicly advocates the formation of another party or the ideologies, interests or policies of another party "shall be deemed to have resigned from the previous political party". 115

What is to be understood is that it suffices to establish the presumption that the previous membership has terminated. The value of written withdrawal notice is apparent when a political party member simply joins or establishes another political party without notifying the political party of his/her previous membership. In such cases, confusion and controversy could be created whether the political party member can take membership in another political party without a written resignation notice to the former political party. The Kenyan Political Parties' Act has, however, validly avoided the potential confusion and controversy by clearly providing for other grounds for presuming withdrawal from political party membership other than a written withdrawal notice.

Therefore, the prohibition of simultaneous membership in more than one political party under the Kenyan Political Parties' Act does not mean that a member of a given political party cannot withdraw from her/his membership and be member of another political party unless written withdrawal notice is submitted to the former party. Particularly, if it is known that s/he has been a member of another political party, the presumption is that $\mathrm{s} /$ he has resigned from his/her previous political party membership.

\section{Issues Related to Freedom of Political Party Membership in Ethiopia}

\subsection{Freedom of political party membership}

The FDRE Constitution recognizes the right to freedom of political party membership. The Constitution ensures the right to freedom of association for any lawful purpose. ${ }^{116}$ This includes the right to association for political purposes and hence it is the foundation for the freedom to form or join a political party. Similarly, it ensures the right to vote and be elected by providing that everyone has the right to be member to and be elected into a position in

\footnotetext{
14 Id., Section 14(1) (a) to (c).

${ }^{115}$ Id., Section 14(5). It provides “... notwithstanding the provisions of subsection (1) or the provisions of any other written law ...”

${ }^{116}$ FDRE Constitution, supra note 1, Article 31.
} 
organizations such as labour unions, civic organizations, employers or professional associations and, this includes the right to membership to political organizations -i.e. political parties- provided that s/he meets the specific admission requirements. ${ }^{117}$

On the other hand, the Constitution provides that sovereignty of Ethiopia's Nations, Nationalities and Peoples and the right of individuals to participate in the conduct of public affairs are expressed either by direct participation or through elected representatives. ${ }^{118}$ Moreover, it is provided that political power is assumed and government is led by a political party or coalition of political parties having the highest number of seats in the House of Peoples' Representatives. ${ }^{119}$ These constitutional provisions recognize the instrumentality of political parties for the working of representative democracy and hence reinforce the right to wilful political party membership.

The details of these constitutional rights are regulated by other subordinate laws. In the federal arrangement in Ethiopia, the power to legislate on issues relating to elections and political parties is given to the federal government. ${ }^{120}$ Accordingly, the House of Peoples Representatives has proclaimed three laws: the Electoral Law, ${ }^{121}$ the Political Parties Registration Proclamation, ${ }^{122}$ and Electoral Code of Conduct of Political Parties Proclamation. ${ }^{123}$ These proclamations regulate the details regarding the rights to political party membership and participation in elections. They pledge to achieve the national goal of establishing a democratic system of government with power held only by those who are elected in an open, free, fair and genuinely competitive secret ballot. ${ }^{124}$

These laws are aimed at giving practical effect to the constitutional right to freedom of political party membership and other electoral rights. To this end, it has been provided in the Political Parties Registration Proclamation that every Ethiopian has the right to form or to be a member of a political party except that judges, members of the Defense Force and members of the Police Force cannot

\footnotetext{
${ }^{117}$ Id., Article 38(2) to (4).

${ }^{118}$ Id., Article 8(3) and 38(1).

${ }^{119}$ Id., Article 56 and 73(2).

${ }^{120}$ Id., Article 51(15) and 55(2)(d).

${ }^{121}$ Electoral Law of Ethiopia Amendment Proc. No. 532/2007 (25 $5^{\text {th }}$ June 2007) $13^{\text {th }}$ Year, No. 54 Federal Negarit Gazeta (Addis Ababa) (hereinafter called Electoral Law).

${ }^{122}$ Political Parties Registration Proclamation, supra note 13.

${ }^{123}$ Electoral Code of Conduct of Political Parties Proc. No. 662/2009 (28 ${ }^{\text {th }}$ August 2009) $15^{\text {th }}$ Year, No. 8 Federal Negarit Gazeta (Addis Ababa) (hereinafter called Electoral Code of Conduct)

${ }^{124}$ Electoral Law, supra note 121, see the Preamble and Art. 5; Political Parties Registration Proclamation, supra note 13, see the Preamble and Electoral Code of Conduct, supra note 136, see the Preamble.
} 
be members of a political party unless they leave their work. ${ }^{125}$ The freedom of political party membership is also reinforced by the provision in the Electoral Law that any government employee, except a judge, a policeman/policewoman or soldier may run for election as a private candidate or a member of a political organization. ${ }^{126}$

The Political Parties Registration Proclamation also provides for the substantive and procedural requirements for the formation of political parties. Political parties may be country-wide or regional. ${ }^{127}$ A political party can be formed as country-wide political party if "it has at least [one thousand five hundred] founding members". ${ }^{128}$ Of these, "at least forty percent” are required to be residents of one regional state and the other remaining members are required to be "residents of at least four" regional states fifteen percent in each region. ${ }^{129}$ For a regional political party to be formed, it needs to have "at least [seven hundred fifty] founding members" and of these "more than sixty percent" should be residents of the regional state in which the party is registered to run. ${ }^{130}$

To participate in elections, a political party is required to be registered in the National Electoral Board (the Board) and acquire a legal personality. ${ }^{131}$ Application for registration -signed by the leadership of the party-is required to be presented to the Board accompanied by its memorandum of association, its political program, its by-laws, names and addresses of its leadership and auditor (with documents which show that the leaders of the party are elected in a general assembly). ${ }^{132}$ Before registering a political party, the Board issues a notice that invites any opposition to be presented within fourteen days. ${ }^{133}$ Where the Board finds reasons to refuse registration of a political party, it gives its written decision, and the party whose registration is not accepted can petition to the Federal High Court within fourteen days of the notice of refusal of registration. ${ }^{134}$

The Political Parties Registration Proclamation has specified political parties and institutions that are ineligible to be registered as political parties. Political parties formed for unlawful purposes such as preaching war and hatred and

${ }^{125}$ Political Parties Registration Proclamation, supra note 13, Article 4(1) cum. Article 58 (1) and (2).

${ }^{126}$ Electoral Law, supra note 121, Article 47 (1)(a) and (3).

${ }^{127}$ Political Parties Registration Proclamation, supra note 13, Article 4(2).

${ }^{128}$ Id., Article 5(1) (a)

${ }^{129}$ Id., Article 5(1) (b)-(d)

${ }^{130}$ Id., Article 6(1) (a) and (b)

${ }^{131}$ Id., Article 7(1) and (2).

${ }^{132}$ Id., Article 8(1) and (2)(a)-(g) and Article 12.

${ }^{133}$ Id., Article 9(2) and (3).

${ }^{134}$ Id., Article 9(9) and (10). 
subverting the constitutional order or having foreign nationals as their members cannot be formed and registered. ${ }^{135}$ Similarly, commercial or industrial associations or organizations such as trade unions, professional associations, self-help associations, religious organizations and social associations like iqub and idir are ineligible to be registered as political parties. ${ }^{136}$

After a political party is formed and duly registered, having fulfilled the substantive and procedural requirements, it can admit members according to its by-laws. Members of a political party, therefore, include the founders and other members admitted after its formation. ${ }^{137}$ It is expected that individuals choose the political party of their membership after having examined party programs and policies. To this end, the law provides that membership to political party cannot be transferred by succession or by any other manner to another person and is limited to the member in person. ${ }^{138}$

It is understood from the provisions of the Constitution and the other proclamations highlighted above that the freedom to political party membership has been guaranteed and, no one can be forced to join or belong to any political association against her/his free will. It is, however, to be noted that the freedom to join to a political party also involves the other side of the coin -i.e. the freedom to withdraw from membership. The effectiveness of the right to political party membership is determined not only based on the provisions for the freedom to join, but are also based on the provisions for procedures, conditions and formalities of withdrawal from membership. Thus, unjustified withdrawal procedures adversely affect freedom of membership.

\subsection{Freedom to withdraw from political party membership}

\subsubsection{Termination of membership: expulsion and withdrawal}

The Political Parties Registration Proclamation provides for the termination of political party membership in two ways. These are disciplinary expulsion ${ }^{139}$ and voluntary withdrawal. ${ }^{140}$ The Proclamation provides that any member of any political party may be expelled from membership according to the party's bylaws. ${ }^{141}$ And, a member so expelled and who alleges that her/his expulsion is in violation of the party by-laws can lodge an appeal to the Federal High Court within three months from the date of the notification of such expulsion. ${ }^{142}$

\footnotetext{
${ }^{135}$ Id., Article 10.

${ }^{136}$ Id., Article 11.

${ }^{137}$ Id., Article 31(1).

${ }^{138}$ Id., Article 31(2).

${ }^{139}$ Id., Article 30(1).

${ }^{140}$ Id., Article 31(3).

${ }^{141}$ Id., Article 30(1).

${ }^{142}$ Id., Article 30(2).
} 
The law, on the other hand, provides that "a member of a political party may at any time withdraw from his membership". ${ }^{143}$ Although this provision entitles a political party member the right to leave membership at any time, it does not clearly provide for the detail procedures and forms of withdrawal. Particularly, a question arises whether withdrawal is impossible unless a withdrawing member gives notice in writing to the political party. This author argues that the answer to this question seems to be in the negative.

Although the phrase "at any time", in Article 31(3) of the Political Parties Registration Proclamation seems to make reference to time, and not form, it does not require any condition or any formality. This is because if we attach any formality or condition, withdrawal becomes impossible unless formalities or conditions are met. Likewise, the law does not expressly provide for the requirement of a written withdrawal notice. This entitles a political party member to express her/his intention to withdraw not only by written notice, rather by other ways - such as acquiring a new membership in another political party as in the case of Unity for Justice and Democracy Party v. Blue Party in our discussion.

What reasonably is understood from this is that the express provision in the law as to time has a message implied within it as to form which entitles a political party member to withdraw even without a written notice. Therefore, a political party member cannot be prohibited from leaving membership and taking new membership in another political party on the account of failure to notify the political party of her/his previous membership in writing.

In Unity for Justice and Democracy Party -v.- Blue Party, the requirement of written notice, as stated earlier, has been a point of contention. In this case, the Cassation Bench of the Federal Supreme Court has decided that a political party member cannot withdraw from his membership and be a member and election candidate of another political party without a written withdrawal notice to the political party of her/his previous membership. The court stated that a political party cannot admit former members of another political party as its members and nominate them as election candidates without making sure that they have withdrawn from their previous political party membership upon a written notice. The court, while so ruling, opines that this violates the peaceable relationship between political parties on the one hand and the required loyalty of members to the political party of their membership on the other. The court also stated that this is in violation of the legal requirements to participate in election and the right of the electorate (public) to have informed choices. Section 4.2.2 examines the requirement of a written withdrawal notice in light of the Cassation Bench's premises.

${ }^{143}$ Id., Article 31(3). 


\subsubsection{The requirement of written withdrawal notice and related issues}

a) Interparty relations and their members: reciprocal rights and duties

Peaceful interparty relation is required for the development of a democratic political culture. To this end, it is provided that political parties are required to obey the electoral laws and the electoral code of conduct. ${ }^{144}$ Particularly, political parties are required to make all possible efforts to have continuous communication with other parties. ${ }^{145}$ To enhance the peaceable relationship between political parties, joint political parties' council is also established. ${ }^{146}$ Similarly, election campaigns are required to be conducted without contravening the Constitution and other laws, by respecting the rights of other parties, and without the use of defamatory, inflammatory and violent languages and materials. ${ }^{147}$ Moreover, to strengthen their role in electoral democracy, political parties can form a union, ${ }^{148}$ a front ${ }^{149}$ or a coalition. ${ }^{150}$ These legal provisions are meant to facilitate peaceful interparty relations based on mutual respect whereby political parties will be able to effectively achieve their role of presenting alternative views to the electorate.

The basic rights and duties of political party members are provided by law. Accordingly, political party members have the right to democratic participation in decision-making and to be elected for positions in the political party. ${ }^{151}$ They have also the duty to pay membership dues, the duty to observe party by-laws and the duty to fulfil the admission and election requirements set by the political parry according to party by-laws. ${ }^{152}$

A question relevant here is whether a political party can -in its by-lawsrequire written notice from a member who wants to leave the party. A political party is free to regulate its internal affairs in its by-laws. It, particularly, has the freedom to determine "the procedures of adopting and amending its political programs and by-laws", the admission requirements of members and details of membership rights and duties. ${ }^{153}$ Party by-laws cannot, however, abridge the rights of a member guaranteed by the law, or relieve a member from a duty imposed on citizens. ${ }^{154}$ Party by-laws are also required to be consistent with the

\footnotetext{
${ }^{144}$ Electoral Code of Conduct, supra note 123, Article 7.

${ }^{145}$ Id., Article 16.

${ }^{146}$ Id., Article 16 and 20-22.

${ }^{147}$ Id., Article 11; see also Electoral Law, supra note 121, Article 58.

${ }^{148}$ Political Parties Registration Proclamation, supra note 13, Article 32.

${ }^{149}$ Id., Article 34.

${ }^{150}$ Id., Article 35.

${ }^{151}$ Id., Article 28.

${ }^{152}$ Id., Article 29 and 15. See also FDRE Constitution, supra note 1, Article 38(2)

${ }^{153}$ Id., Article 15(1) \&16 and FDRE Constitution, supra note 1, Article 38(2)

${ }^{154}$ Id., Article 15(2).
} 
rights and duties of the political party members provided in law. ${ }^{155}$ One of the rights of political party members, as argued earlier, is the right to withdraw at any time without necessarily being required to submit a written withdrawal notice. Hence, it is not legal for a political party to provide for a mandatory requirement of withdrawal notice if a member opts to give an end to his/her membership.

Therefore, a political party member can withdraw from his membership and be a member of another political party without a written withdrawal notice to the political party of her/his previous membership. In effect, a political party can accept former members of another political party as its members without the need to ask whether the individuals (it is accepting as members) have notified the political party of their previous membership in writing. This cannot be understood as violation of the duty to have peaceful interparty relationship. Nor can the acts of withdrawing party members (without written notice) be considered as violation of party by-laws.

At this juncture, it is important to see the requirement for a written withdrawal notice and the legal effect of its non-observance in light of the interests of both the political party (from which a member is withdrawing) and the withdrawing member. Political parties have interest in updating data about their members who have sustained their membership, and those who have left. This enables political parties to update their register and to effectively communicate with their members. ${ }^{156}$ Thus the only viable interest of a political party in requiring a written notice from its withdrawing members can only be updating data regarding members. On the one hand, the political party member has the right to free political association and particularly the right to withdraw from political party membership which shall not be limited except for reasonably acceptable purposes.

Seen from the practical viewpoint, political parties can know the members who have withdrawn without necessarily requiring a mandatory written withdrawal notice. Especially, in cases where a political party member is found to have taken new membership in another party, this is sufficient expression that $\mathrm{s} /$ he does not want membership in the former political party. For example, in Unity for Justice and Democracy Party v. Blue Party, the petitioner had already known that its former members have taken new membership in another political party -i.e. the respondent- by the simple fact that they were nominated and registered as election candidates of the respondent. This is sufficient notice for the purpose of knowing that its members have withdrawn their membership, and

\footnotetext{
${ }^{155}$ Id., Article 15(3) \&31(4).

${ }^{156}$ See Michael Chege (2007), Political Parties in East Africa: Diversity in Political Party Systems, International Institute for Democracy and Electoral Assistance (IDEA) p. 47.
} 
thus the requirement of a written withdrawal notice under such settings does not have practical significance.

\section{b) Issues related to candidature in election}

The Electoral Law embodies certain requirements that apply for private candidates, political party nominees and political parties that participate in an election. Accordingly, any person (a private candidate or a political party nominee) who wants to campaign in an election should be an Ethiopian National, "versed with the language of the Regional State or area of his/her intended candidature", aged at least twenty-one years and regularly residing or working in the area of her/his candidature for two years immediately preceding registration. ${ }^{157}$

In addition to the aforementioned requirements, a private candidate is required to present endorsement signatures of one thousand eligible voters who are certified residents of the constituency of her/his candidature. ${ }^{158}$ Similarly, in order for a political party to compete in an election it needs to be duly registered and present a qualified nominee. ${ }^{159}$ Even though party nominees are exempted from the requirement of presenting endorsement signatures of one thousand qualified electors, evidence of their nomination including evidence of their consent for the nomination "along with details of candidature" is required to be presented to the Electoral Board. ${ }^{160}$

The phrase "details of candidature" (understood in light of its context) relates to candidature and the manner in which political party candidates are elected. This envisages the presentation of evidence to show that candidates are elected in a democratic manner with due participation of political party members as provided in the FDRE Constitution and in the Political Parties' Registration Proclamation. ${ }^{161}$ This is meant to develop intraparty democracy.

The Electoral Law, on the other hand, provides that political party nominees and private candidates registered for an election can withdraw from election. ${ }^{162}$ Particularly, it is provided in the Electoral Law that "A political party candidate who has withdrawn from the election ... shall notify his decision in writing to the political party that nominated him". ${ }^{163}$ Whether or not this provision can be

${ }^{157}$ Electoral Law, supra note 121, Article 45(1) and (2).

${ }^{158}$ Id., Article 45(3).

${ }^{159}$ Id., Article 46(1)

${ }^{160}$ Id., Article 46(2) \& (3).

161 FDRE Constitution, supra note 1, Article 38(3) and Political Parties Registration Proclamation, supra note 13, Article 28, 15(1)(b), (d), (e) and (i).

${ }^{162}$ For the withdrawal and replacement of candidates, see Electoral Law, supra note 121, Article 54.

${ }^{163}$ Id., Article 54(2). 
construed -by analogy - to require a political party member who withdraws from his/her membership to notify the political party of her/his membership in writing can be an issue.

However, there is a difference between a political party nominee withdrawing from an election and a political party member withdrawing from her/his membership. A political party candidate, as opposed to a member not nominated as a candidate for election, represents the political party which nominated her/him and competes in the election. In this regard, the purpose why the Electoral Law requires a political party candidate who withdraws from an election to notify the political party that has nominated her/him in writing is to enable the political party whose nominee has withdrawn to nominate a substitute candidate for the election. ${ }^{164}$ On the contrary, however, in the case of a political party member withdrawing from his/her membership, there is no interest of nominating a substitute candidate. Thus, there is no need for a withdrawing member to submit a written withdrawal notice to the political party of his/her previous membership.

\section{c) The right of the electorate (public) to have informed choice}

One of the purposes of a multiparty election is to enable citizens to exercise their constitutional rights to vote and be elected ${ }^{165}$ in the context of multiple alternatives and free choice. For this to be achieved, there should be sufficient communication between the electorate and political parties or private candidates contesting in an election. To this end, there are mechanisms provided for in the Electoral Law. These include conducting election campaigns and the use of distinctive symbols and designations.

The Electoral Law provides that every candidate - who has been given candidature Identification Card- can conduct election campaigns in a peaceful and democratic manner respecting the Constitution and relevant laws until "two days before" the polling date. ${ }^{166}$ It is also provided that political organizations and their supporters shall have "equal access to state owned mass media including radio, TV and newspapers”. ${ }^{167}$ Particularly, candidates are entitled to have "access to free airtime on the state-owned media". ${ }^{168}$ For these rights to materialize, Government organs have the obligation of creating conducive conditions. ${ }^{169}$

\footnotetext{
${ }^{164}$ Id., Article 54(2) cum 54(4).

${ }^{165}$ Id., Article 5; see also Electoral Code of Conduct, supra note 123, Article 5.

${ }^{166}$ Id., Article 58(1)-(5).

${ }^{167}$ Id., Article 59(1).

${ }^{168}$ Id., Article 59(2).

169 Id., Article 60.
} 
To avoid confusion about symbols and designations, political parties and candidates in an election campaign are required to use distinctive symbols. ${ }^{170}$ Political parties are also prohibited from imitating, stealing, disfiguring or destroying the symbols of other political parties. ${ }^{171}$ Moreover, it is provided that the designation, emblem and flag of a political party shall not be similar or shall not create confusion with that of other political parties or commercial, social or international organizations. ${ }^{172}$

If these legal requirements are duly observed, political parties and candidates will be able to sufficiently present their policy alternatives to the electorate, and the public will be able to have sufficient information so that it can decide whom to vote for without any confusion. The legal regime thus clearly facilitates informed choice, and a political party member's withdrawal from her/his former political party without written notice cannot create a problem with respect to the informed decision of the electorate.

\subsection{The possible challenges of simultaneous political party membership}

The foregoing analysis shows that political party members have the right to withdraw from membership and take new membership in another political party of their choice at any time even without written notice to the political party of their previous membership. However, there is the need to caveats against simultaneous party membership. If political party members are given the right to withdraw from their membership at any time without written notice and take membership in another political party, this may be an incentive for simultaneous membership. This calls for a mechanism to deter simultaneous membership without unduly hindering the freedom to join to and withdraw from political party.

The fact that a political party member has withdrawn from his/her previous membership and taken new membership in another political party without a written notice to the political party of her/his previous membership does not mean s/he has been a member simultaneously to more than one political party. An individual can be said to have taken membership in different parties simultaneously if s/he accepts simultaneous nomination by more than one political party. In the eyes of reasonable political system, in fact, we assume that individuals choose a political party of their membership having examined the political party's policies as established in political party programs and intraparty democracy as stipulated in party by-laws. We can thus assume that a reasonable person may not be a member of and accept simultaneous nomination as a

\footnotetext{
${ }^{170}$ Id., Article 52.

${ }^{171}$ Electoral Code of Conduct, supra note 123, Article 12.

${ }^{172}$ Id., Article 27 (1) \& (2)
} 
candidate by two political parties for an election. But, if this occurs due to a desire to secure seat in parliament, this will be illegal and of no effect.

Once it is agreed that acceptance of simultaneous nomination amounts to simultaneous political party membership and so illegal, the next issue then becomes how this risk can be prevented and remedied. Two mechanisms can be recommended to avoid simultaneous political party membership without limiting the freedom of political party members to resign from their previous membership at any time and take membership in another political party.

The first mechanism is the development of verified and updated register of political party members. The experience of other jurisdictions shows that provisions in the party laws require membership rolls of political parties to be cross-checked in specified time intervals. In Israel, for example, the registrar of political parties is entrusted with this task, and a coding technology system has been recommended -to respect the privacy of individual political party members. ${ }^{173}$ Similarly, political parties in Kenya are required to keep the register of their members at their head office and at each county office. ${ }^{174}$ The Kenyan Registrar of Political Parties can also require political parties to present all records, including the register of members, and take copies thereof. ${ }^{175}$ More importantly one of the functions of the Kenyan Registrar of Political Parties is to verify -and make publicly available- the list of all members of political parties. ${ }^{176}$ These procedural requirements enable political parties to identify previous members who have taken new membership in another political party.

The only objective of the Political Parties Registration Proclamation in Ethiopia in requiring political parties to report to the Electoral Board is to make sure that the required number of political party members is complied with. ${ }^{177}$ This seems to be inadequate and the law needs to be amended because political parties should be required to keep updated register of their members and submit such reports to the Board in specified time intervals. At the same time, the Board is expected to be empowered to keep verified register of all political party members and make these records known to the public. This will enable political parties to have sufficient information about their members and especially identify the ones that have taken new membership in another political party, and thereupon correct their records and decide whom to nominate as candidate for elections.

\footnotetext{
${ }^{173}$ Reforming Israel's Political System, supra note 87, p. 18.

${ }^{174}$ Kenyan Political Parties Act, supra note 110, Section 17(1)(a).

${ }^{175}$ Id., Section 18(1) and (2).

${ }^{176}$ Id., Section 34(d).

${ }^{177}$ Political Parties Registration Proclamation, supra note 13, Article 19(1)(a). The required number of members, as already seen earlier, is one thousand five hundred for countrywide parties and seven hundred fifty for regional parties.
} 
The second mechanism can be the inclusion of clear provisions in the Electoral Law which provide for the cancellation of both nominations if an individual is found to have accepted simultaneous nomination by more than one political party for a single election. The Electoral Law provides that a political party can nominate only one candidate for a single council seat at a constituency ${ }^{178}$ It also provides "Any person shall be nominated as a candidate in one constituency only". ${ }^{179}$ From these provisions, it is understood that a political party cannot nominate more than one candidate in a constituency. Similarly, a person cannot run for an election as a candidate in two or more constituencies. However, the law does not embody provisions against simultaneous nominations. Therefore, it needs to be revisited to include a clear provision that simultaneous nomination leads to cancelation from candidature in the election.

\section{Concluding Remarks}

The FDRE Constitution acknowledges freedom of political party membership. The details of political party membership are regulated by the Political Parties Registration Proclamation. This Proclamation endorses the constitutional right to freedom of political party membership and provides for the details of membership rights and duties. One of the rights of a political party member is that s/he can withdraw from her/his membership at any time.

The form of withdrawal, however, seems to be far from clear and has become a point of disagreement. An example for this is Unity for Justice and Democracy Party v. Blue Party, a case finally decided by the Cassation Bench of the Federal Supreme Court. In this case, the petitioner, Unity for Justice and Democracy Party claimed that a person cannot be registered as a member and be nominated as election candidate of another political party without a written withdrawal notice to the political party where s/he has been a member. The respondent, Blue Party on the other side argued that previous membership cannot bar a person from membership in another party, because withdrawal from membership is possible at any time.

The Political Parties Registration Proclamation does not provide for the requirement of written withdrawal notice. It rather entitles political party members with the right to withdraw from membership at any time. Accordingly, political party members can express their intention to withdraw from their membership in different ways other than a written notice of withdrawal. Particularly, once it is known that a member of a political party has taken new membership in another political party, s/he shall be deemed to have terminated

\footnotetext{
${ }^{178}$ Electoral Law, supra note 121, Article 46(4).

${ }^{179}$ Id., Article 56(1).
} 
her/his previous membership upon her/his will. This is in line with the provisions of the FDRE Constitution and international human rights instruments providing for the freedom of association generally, and freedom of political party membership, in particular. This is also supported by the comparative experience of other jurisdictions. Therefore, disallowing new membership in another party on the account of failure to notify the political party of previous membership is an unjust restriction against the full-fledged exercise of the freedom of political party membership.

However, such full-fledged exercise of the freedom of political party membership may be an incentive for individuals to assume simultaneous membership and accept simultaneous nomination as candidate of more than one political party in an election. To avoid this challenge -without limiting the freedom of political party members (to resign from their previous membership at any time and take new membership in another political party)- amendments to the existing laws are recommended. Such amendments in the Political Parties Registration Proclamation is expected to require updated register of political party members and the submission of such reports to the Board in a specified time interval. The Board, at the same time, can be empowered to keep verified register of all political party members and make these records known to the public. This enables the political parties to update their records and to decide whom to nominate as candidate for elections accordingly.

Moreover, the inclusion of clear provisions in the Electoral Law that allow the cancelation of simultaneous nomination is necessary. Such provisions enable the cancellation of all nominations if an individual is found to have accepted simultaneous nomination by more than one political party for an election. This will indeed be a disincentive against acceptance of simultaneous nominations by more than one political party in an election. 